\title{
Effect of Principal Leadership, Teacher Job Satisfaction and Teacher Work Motivation, on the Quality of Education in SMPK Kolose St. Yusuf 2 Malang
}

\author{
Elisabeth Nitra Rini ${ }^{1}$, Syaiful Arifin ${ }^{2}$, Yarnest $^{3}$ \\ ${ }^{1}$ Post Gradute Scholars, Master in Management Program, University of Merdeka Malang, Indonesia \\ ${ }^{2,3}$ Lecturer at the Faculty of Economics and Business, University of Merdeka, Malang, Indonesia
}

\begin{abstract}
This study aimed to determine the effect of the Principal Leadership, Work Motivation and Job Satisfaction on Quality of Education Teacher, simultaneously or partially and find out which of the three independent variables the dominant influence on the Quality of Education. The object of research is limited to the Principal Leadership, Work Motivation, and Job Satisfaction and Teacher as an independent variable in the quality of education as the dependent variable. The number of samples in this study was 50 teachers. The results showed that the test Hypothesis I accepted that School leadership, motivation and job satisfaction of teachers simultaneously affect the quality of education. It can be seen from the value of $F$ indicates a significant level of $0.00<\alpha$ 0.05. Hypothesis II accepted that School leadership, motivation and job satisfaction of teachers partially affect the quality of education. It can be seen from the significant value of three independent variable t respectively of $0.047 \leq \alpha=0.05$, it indicates the working motivation partially significant effect on the quality of education. Uji hypothesis III also accepted that influential teacher job satisfaction dominant the quality of education. It can be seen from the variable beta coefficient greater teacher job satisfaction, namely 0353.
\end{abstract}

Keywords: Principal Leadership, Work Motivation, Teacher Job Satisfaction, Quality Education.

\section{INTRODUCTION}

Education is very important for a person, because education is the process of changing attitudes and procedures of behavior or groups of people in human mature through the efforts of the teaching and training (according to the Indonesian big dictionary) [1], Educational institutions that are effective in improving the quality of education requires a good quality management to face the competitive atmosphere and orientation of the future. The quality or the quality of education that can be achieved if an institution has inputs, processes, outputs, and outcomes of quality. Thus, the quality of education is the end result of the process of education idealized by all educational institutions [2].

The quality of education is inseparable from a variety of factors such as those mentioned above. An educational institution is said to be quality or grade if they meet several important elements in it such as school leadership, teacher job satisfaction, and motivation of teachers. SMPK Kolose St. Yusuf 2 Malang is a Catholic private educational institutions. Educational institutions is certainly not the least experience problems or issues relating to the quality of education [3].

The quality of education is still far instituted with competitors that have not brought satisfaction for the customer education. The problem of education quality in these institutions Firstly, in terms of input is minimal building, classrooms are not equipped with air conditioning, facilities, teaching staff and students who are not skimpy. Secondly, in terms of the process is the method of learning that is less stimulating and enjoyable learners, instructional media that are less supportive, the teacher does not make variations in teaching techniques. Third, in terms of output, namely the study of students still brought the average to make remedial learners should follow. Fourth, in terms of graduates from outcomes is SMPK Kolose St. Yusuf 2 Malang not shown skill in competitive with other competitors institute graduates [4].

Based on the reality on the ground, it appears that the impact of school leadership, motivation and job satisfaction of teachers, in SMPK Kolose St. Yusuf 2 Malang, very important role in improving the quality of education. The lack of effect of school leadership to provide work motivation of teachers and teacher job satisfaction in knowing SMPK Kolose St. Yusuf 2 Malang influences the quality of education. On the basis of the above issues, the issue to be studied is the effect of school leadership, teacher job satisfaction and work motivation of teachers, the quality of education in SMPK Kolose St. Yusuf 2 Malang. 
International Journal of Advances in Scientific Research and Engineering (ijasre), Vol 5 (11), November-2019

\section{METHOD}

This study used quantitative analysis and methods of this research is descriptive analysis. Population and sample in this research is the teachersin SMPK Kolose St. Yusuf 2 Malang, amounting to 50 people,

\section{RESULTS AND DISCUSSION}

Table 1 Characteristics Respondents Based on Type Sex

\begin{tabular}{|c|l|c|c|}
\hline No. & \multicolumn{1}{|c|}{ Gender } & Number of people) & Percentage (\%) \\
\hline 1 & Male & 21 & $42 \%$ \\
\hline 2 & Woman & 29 & $58 \%$ \\
\hline \multicolumn{2}{r|}{ Total } & 50 & 100 \\
\hline
\end{tabular}

Source : Data primary processed, 2019.

Based on table 3 can be known that the majority of respondents are sex women with a number of 29 respondents (58\%), while teachers male sex as much as 21 respondents (58\%).

Table 2 Characteristics Respondents Based on Time Work

\begin{tabular}{|c|l|c|c|}
\hline No. & \multicolumn{1}{|c|}{ Years of service } & Number of people) & Percentage (\%) \\
\hline 1 & 15 years & 10 & $20 \%$ \\
\hline 2 & 6-10 years & 16 & $32 \%$ \\
\hline 3 & More than 10 years & 24 & $48 \%$ \\
\hline \multicolumn{2}{r|}{ Total } & 50 & 100 \\
\hline
\end{tabular}

Source : Data primary processed, 2019.

Based on Table 3 noted that respondents by period working 1-5 years 10 respondents (20\%). respondents with time work 6-10 years 16 respondents (32\%). respondents by period more work 10 years 24 respondents (48\%). Thus the majority respondents have years of service more than 10 years, it this show that respondents experienced in their respective fields.

Table 3 Characteristics Respondents Based on Education

\begin{tabular}{|c|cc|c|c|}
\hline No. & \multicolumn{2}{|c|}{ Education } & Number of people) & Percentage (\%) \\
\hline 1 & S2 & 18 & $36 \%$ \\
\hline 2 & S1 & 32 & $64 \%$ \\
\hline \multicolumn{2}{|c|}{ Total } & 50 & 100 \\
\hline
\end{tabular}

Source : Data primary processed, 2019.

Based on Table 3, it can be known that majority of respondents S1 as many as 32 respondents (64.0\%) than teachers who educated $\mathrm{S} 2$ as much as 18 respondents $(36 \%)$.

Table 4 Validity Leadership Principal (X1)

\begin{tabular}{|c|l|l|c|c|}
\hline Item & r count & r table & Sig & Information \\
\hline Q1 & $0.751^{* *}$ & 0.2787 & 0.000 & valid \\
\hline Q2 & $0.308^{* *}$ & 0.2787 & 0.029 & valid \\
\hline Q3 & $0.528^{* *}$ & 0.2787 & 0.000 & valid \\
\hline Q4 & $0.764^{* *}$ & 0.2787 & 0.000 & valid \\
\hline Q5 & $0.655^{* *}$ & 0.2787 & 0.000 & valid \\
\hline Q6 & $0.638^{* *}$ & 0.2787 & 0.000 & valid \\
\hline Q7 & $0.720^{* *}$ & 0.2787 & 0.000 & valid \\
\hline Q8 & $0.565^{* *}$ & 0.2787 & 0.000 & valid \\
\hline Q9 & $0.458^{* *}$ & 0.2787 & 0.001 & valid \\
\hline Q10 & $0.441^{* *}$ & 0.2787 & 0.001 & valid \\
\hline Q11 & $0.608^{* *}$ & 0.2787 & 0.000 & valid \\
\hline
\end{tabular}


International Journal of Advances in Scientific Research and Engineering (ijasre), Vol 5 (11), November-2019

\begin{tabular}{|l|l|l|l|l|}
\hline Q12 & $0.632^{* * *}$ & 0.2787 & 0.000 & valid \\
\hline Q13 & $0.716^{* *}$ & 0.2787 & 0.000 & valid \\
\hline Q14 & $0.516^{* *}$ & 0.2787 & 0.000 & valid \\
\hline Q15 & $0.634^{* *}$ & 0.2787 & 0.000 & valid \\
\hline Q16 & $0.567^{* *}$ & 0.2787 & 0.000 & valid \\
\hline Q17 & $0.352^{* *}$ & 0.2787 & 0.012 & valid \\
\hline
\end{tabular}

Sources: Primary data is processed in 2019.

From Table 4 above shows that the value of $\mathrm{r}$ count each question item is greater than the value on the table and $\mathrm{df}=50-2$ $=48$ at 0.2787 and the probability is less than $\%$. It can be concluded 17 items declared valid questions that can be used to measure the variables Leadership Principal. $\alpha=0,05 \alpha=5$

Table 5 Test Validity Work Motivation (X2)

\begin{tabular}{|c|c|c|c|c|}
\hline item & r count & r table & Sig & Information \\
\hline Q18 & $0.842^{* *}$ & 0.2787 & 0.000 & valid \\
\hline Q19 & $0.686^{* *}$ & 0.2787 & 0.000 & valid \\
\hline Q20 & $0.572^{* *}$ & 0.2787 & 0.000 & valid \\
\hline Q21 & $0.545^{* *}$ & 0.2787 & 0.000 & valid \\
\hline Q22 & $0.601^{* *}$ & 0.2787 & 0.000 & valid \\
\hline Q23 & $0.650^{* *}$ & 0.2787 & 0.000 & valid \\
\hline Q24 & $0.630^{* *}$ & 0.2787 & 0.000 & valid \\
\hline Q25 & $0.674^{* *}$ & 0.2787 & 0.003 & valid \\
\hline Q26 & $0.522^{* *}$ & 0.2787 & 0.008 & valid \\
\hline Q27 & $0.525^{* *}$ & 0.2787 & 0.000 & valid \\
\hline Q28 & $0.391^{* *}$ & 0.2787 & 0.005 & valid \\
\hline Q29 & $0.651^{* * *}$ & 0.2787 & 0.000 & valid \\
\hline Q30 & $0.784^{* *}$ & 0.2787 & 0.000 & valid \\
\hline Q31 & $0.737^{* *}$ & 0.2787 & 0.000 & valid \\
\hline Q32 & $0.479^{* *}$ & 0.2787 & 0.000 & \\
\hline
\end{tabular}

Sources: Primary data is processed in 2019

From Table 5 above shows that the value of $\mathrm{r}$ count each question item is greater than the value on the table and $\mathrm{df}=50-2$ $=48$ at 0.2787 and the probability is less than\%. It can be concluded 15 items be expressed valid questions that can be used to measure the variable work motivation. $\alpha=0,05 \alpha=5$.

Table 6 Teacher Job Satisfaction Validity Test (X3)

\begin{tabular}{|l|l|l|l|c|}
\hline \multicolumn{1}{|c|}{ Item } & r count & r table & Sig & information \\
\hline Q33 & $0.594^{* *}$ & 0.2787 & 0.000 & valid \\
\hline Q34 & $0.461^{* *}$ & 0.2787 & 0.001 & valid \\
\hline Q35 & $0.476^{* * *}$ & 0.2787 & 0.000 & valid \\
\hline Q36 & $0.487^{* *}$ & 0.2787 & 0.000 & valid \\
\hline Q37 & $0.290^{* *}$ & 0.2787 & 0.041 & valid \\
\hline Q38 & $0.479^{* *}$ & 0.2787 & 0.000 & valid \\
\hline Q39 & $0.660^{* *}$ & 0.2787 & 0.000 & valid \\
\hline Q40 & $0.570^{* *}$ & 0.2787 & 0.000 & valid \\
\hline Q41 & $0.348^{* *}$ & 0.2787 & 0.013 & valid \\
\hline
\end{tabular}

Sources: Primary data is processed in 2019

From Table 6 above shows that the value of $\mathrm{r}$ count each question item is greater than the value on the table and $\mathrm{df}=50-2$ $=48$ at 0.2787 and the probability is less than\%. It can be concluded 9 items be expressed valid questions that can be used to measure variables Teacher Job Satisfaction. $\alpha=0,05 \alpha=5$ 
International Journal of Advances in Scientific Research and Engineering (ijasre), Vol 5 (11), November-2019

Table 7 Validity of Quality Education (Y)

\begin{tabular}{|c|c|c|c|c|}
\hline Item & $\mathrm{r}$ count & $\mathrm{r}$ table & Sig & information \\
\hline $\mathrm{Q} 42$ & $0.750^{* *}$ & 0.2787 & 0.000 & valid \\
\hline Q43 & $0.622^{* *}$ & 0.2787 & 0.000 & valid \\
\hline Q44 & $0.768^{* *}$ & 0.2787 & 0.000 & valid \\
\hline Q45 & $0.419^{* *}$ & 0.2787 & 0.002 & valid \\
\hline Q46 & $0.610^{* *}$ & 0.2787 & 0.000 & valid \\
\hline Q47 & $0.543^{* *}$ & 0.2787 & 0.000 & valid \\
\hline Q48 & $0.306 * *$ & 0.2787 & 0.031 & valid \\
\hline Q49 & $0.493^{* *}$ & 0.2787 & 0.000 & valid \\
\hline Q50 & $0.505^{* *}$ & 0.2787 & 0.000 & valid \\
\hline Q51 & $0.633^{* *}$ & 0.2787 & 0.000 & valid \\
\hline
\end{tabular}

Sources: Primary data is processed in 2019.

From Table 7 above shows that the value of $\mathrm{r}$ count each question item is greater than the value on the table and $\mathrm{df}=50-2$ $=48$ at 0.2787 and the probability is less than $\%$. It can be concluded 10 items be expressed valid questions that can be used to measure the Education Quality variable. $\alpha=0,05 \alpha=5$

\subsection{Test Reliability}

A tool called reliable if respondents consistently in charge of measuring instruments or a list of questions. The reliability indicates the extent to which the measurement results remain consistent.

Table 8 Relebialitas Test Variables

\begin{tabular}{|l|l|c|c|}
\hline No. & \multicolumn{1}{|c|}{ variables } & Value Cronbach Alpha & Information \\
\hline 1 & Leadership Principal (X1) & 0748 & reliable \\
\hline 2 & Work Motivation $(\mathrm{X} 2)$ & 0753 & reliable \\
\hline 3 & Teacher Job Satisfaction $(\mathrm{X} 3)$ & 0700 & reliable \\
\hline 4 & Quality of Education $(\mathrm{Y})$ & 0752 & reliable \\
\hline
\end{tabular}

Sources: Primary data is processed in 2019

Based on Table 8 above shows that the value of Cronbach Alpha of each variable is greater than 0.6 it can be concluded all the items of the questions used to measure the variable is declared reliable, meaning that the instrument used was very consistent or reliable.

\subsection{Result Variable Descriptions.}

Variable Description Principal Leadership.

Table 9 Variable Description Principal Leadership (X1)

\begin{tabular}{|c|c|c|c|c|c|c|c|c|c|c|c|c|c|}
\hline \multirow{3}{*}{ Item } & \multicolumn{10}{|c|}{ Answer } & \multirow{3}{*}{$\mathrm{N}$} & \multirow{3}{*}{$\begin{array}{l}\text { Total } \\
\text { score }\end{array}$} & \multirow{3}{*}{ Mean } \\
\hline & \multicolumn{2}{|c|}{5} & \multicolumn{2}{|c|}{4} & \multicolumn{2}{|c|}{3} & \multicolumn{2}{|c|}{2} & \multicolumn{2}{|c|}{1} & & & \\
\hline & $\mathrm{F}$ & $\%$ & $\mathrm{~F}$ & $\%$ & $\mathrm{~F}$ & $\%$ & $\mathrm{~F}$ & $\%$ & $\mathrm{~F}$ & $\%$ & & & \\
\hline Q1 & 31 & 62 & 16 & 32 & 3 & 6 & 0 & 0 & 0 & 0 & 50 & 228 & 4.60 \\
\hline Q2 & 33 & 66 & 17 & 34 & 0 & 0 & 0 & 0 & 0 & 0 & 50 & 233 & 4.70 \\
\hline Q3 & 25 & 50 & 23 & 46 & 0 & 0 & 2 & 4 & 0 & 0 & 50 & 221 & 4.40 \\
\hline Q4 & 27 & 54.0 & 23 & 46 & 0 & 0 & 0 & 0 & 0 & 0 & 50 & 227 & 4.50 \\
\hline Q5 & 10 & 20 & 30 & 60 & 10 & 20 & 0 & 0 & 0 & 0 & 50 & 200 & 4.00 \\
\hline Q6 & 12 & 24 & 30 & 60 & 8 & 16 & 0 & 0 & 0 & 0 & 50 & 204 & 4.10 \\
\hline Q7 & 18 & 36 & 27 & 54 & 5 & 10 & 0 & 0 & 0 & 0 & 50 & 213 & 4.30 \\
\hline Q8 & 4 & 8 & 36 & 72 & 10 & 20 & 0 & 0 & 0 & 0 & 50 & 194 & 3.90 \\
\hline Q9 & 9 & 18 & 40 & 80 & 1 & 2 & 0 & 0 & 0 & 0 & 50 & 208 & 4.20 \\
\hline Q10 & 22 & 44 & 28 & 56 & 0 & 0 & 0 & 0 & 0 & 0 & 50 & 222 & 4.40 \\
\hline Q11 & 15 & 30 & 35 & 70 & 0 & 0 & 0 & 0 & 0 & 0 & 50 & 215 & 4.30 \\
\hline Q12 & 8 & 16 & 39 & 78 & 3 & 6 & 0 & 0 & 0 & 0 & 50 & 205 & 4.10 \\
\hline Q13 & 12 & 24 & 35 & 70 & 3 & 6 & 0 & 0 & 0 & 0 & 50 & 209 & 4.20 \\
\hline
\end{tabular}


International Journal of Advances in Scientific Research and Engineering (ijasre), Vol 5 (11), November-2019

\begin{tabular}{|c|c|c|c|c|c|c|c|c|c|c|c|c|c|}
\hline Q14 & 11 & 22 & 37 & 74 & 2 & 4 & 0 & 0 & 0 & 0 & 50 & 209 & 4.20 \\
\hline Q15 & 23 & 46 & 24 & 48 & 3 & 6 & 0 & 0 & 0 & 0 & 50 & 220 & 4.40 \\
\hline Q16 & 13 & 26 & 35 & 70 & 2 & 4 & 0 & 0 & 0 & 0 & 50 & 211 & 4.20 \\
\hline Q17 & 5 & 10 & 41 & 82 & 4 & 8 & 0 & 0 & 0 & 0 & 50 & 201 & 4.00 \\
\hline \multicolumn{11}{|c|}{ Total Variable Leadership Principal } \\
\hline \multicolumn{11}{|c|}{ avene variable Principal Leadership } \\
\hline
\end{tabular}

Source: Data Processed in 2019

From Table 9 above it can be seen that of the 17 items of 50 respondents answer on school leadership to the average score of school leadership (X1) of 4.26 thereby indicating that respondents tend to agree that school leadership is able to contribute to the quality of education. The variable frequency distribution table of the principal's leadership of the most high of $4.70 \%$ in Q2 which is the principal new ideas in learning. New ideas in learning can build on the progress of educational institutions. While the lowest value of the variable frequency distribution of school leadership is 3.90\% Q8 statement contained in the item that is the principal gave sanction for noncompliance [5].

Variable Descriptions Work Motivation

Table 10 Variable X2 Work Motivation

\begin{tabular}{|c|c|c|c|c|c|c|c|c|c|c|c|c|c|}
\hline \multirow{3}{*}{ Item } & \multicolumn{10}{|c|}{ answer } & \multirow{3}{*}{$\mathrm{N}$} & \multirow{3}{*}{$\begin{array}{l}\text { Total } \\
\text { Score }\end{array}$} & \multirow{3}{*}{ Mean } \\
\hline & \multicolumn{2}{|c|}{5} & \multicolumn{2}{|c|}{4} & \multicolumn{2}{|c|}{3} & \multicolumn{2}{|c|}{2} & \multicolumn{2}{|c|}{1} & & & \\
\hline & $\mathrm{F}$ & $\%$ & $\mathrm{~F}$ & $\%$ & $F$ & $\%$ & $\mathrm{~F}$ & $\%$ & $\mathrm{~F}$ & $\%$ & & & \\
\hline Q18 & 10 & 20 & 31 & 62 & 9 & 18 & 0 & 0 & 0 & 0 & 50 & 201 & 4.02 \\
\hline Q19 & 5 & 10 & 31 & 62 & 14 & 28 & 0 & 0 & 0 & 0 & 50 & 191 & 3.82 \\
\hline Q20 & 7 & 14 & 32 & 64 & 11 & 22 & 0 & 0 & 0 & 0 & 50 & 196 & 3.92 \\
\hline Q21 & 4 & 8 & 38 & 76 & 8 & 16 & 0 & 0 & 0 & 0 & 50 & 196 & 3.92 \\
\hline Q22 & 5 & 10 & 41 & 82 & 4 & 8 & 0 & 0 & 0 & 0 & 50 & 201 & 4.02 \\
\hline Q23 & 3 & 6 & 35 & 70 & 12 & 24 & 0 & 0 & 0 & 0 & 50 & 191 & 3.82 \\
\hline Q24 & 12 & 24 & 34 & 68 & 4 & 8 & 0 & 0 & 0 & 0 & 50 & 208 & 4.16 \\
\hline Q25 & 11 & 22 & 39 & 78 & 0 & 0 & 0 & 0 & 0 & 0 & 50 & 211 & 4.22 \\
\hline Q26 & 6 & 12 & 38 & 76 & 6 & 12 & 0 & 0 & 0 & 0 & 50 & 200 & 4.00 \\
\hline Q27 & 13 & 26 & 32 & 64 & 5 & 10 & 0 & 0 & 0 & 0 & 50 & 208 & 4.16 \\
\hline Q28 & 4 & 8 & 39 & 78 & 7 & 14 & 0 & 0 & 0 & 0 & 50 & 197 & 3.94 \\
\hline Q29 & 5 & 10 & 41 & 82 & 4 & 8 & 0 & 0 & 0 & 0 & 50 & 201 & 4.02 \\
\hline Q30 & 6 & 12 & 41 & 82 & 3 & 6 & 0 & 0 & 0 & 0 & 50 & 203 & 4.06 \\
\hline Q31 & 6 & 12 & 34 & 68 & 10 & 20 & 0 & 0 & 0 & 0 & 50 & 196 & 3.92 \\
\hline Q32 & 11 & 22 & 39 & 78 & 0 & 0 & 0 & 0 & 0 & 0 & 50 & 211 & 4.22 \\
\hline \multicolumn{11}{|c|}{ Total Variable Work Motivation } & & & 60.22 \\
\hline \multicolumn{13}{|c|}{ The average variable Work Motivation } & 4.02 \\
\hline
\end{tabular}

Sources: Primary data is processed in 2019

From Table 10 above it can be seen that of the 15 items of 50 respondents answer on work motivation for the average item score of work motivation (X2) 4.02 thereby indicating that respondents tend to agree that motivation to contribute to the quality of education. From the frequency distribution table of work motivation of the most high of 4.16\% in Q24 and Q27 are harmoniously intertwined relationship with the boss and the boss is willing harmonious recognizes and rewards achievement to teachers for the work that has been carried out properly [6]. Certainly here as educators is very important is building a good relationship with the boss and getting awards for achievements in the quality of education can be to achieve a good education. Teachers perform well will receive an award [7]. While the lowest value of the frequency distribution of work motivation is $3.82 \%$ contained in the statement item Q19 and Q23 are benefits paid in accordance with the workload and career as well as future teachers are always secure [8]. Variable Description Teacher Job Satisfaction 
International Journal of Advances in Scientific Research and Engineering (ijasre), Vol 5 (11), November-2019

Table 11 Variable X3 Teacher Job Satisfaction

\begin{tabular}{|c|c|c|c|c|c|c|c|c|c|c|c|c|c|}
\hline \multirow{3}{*}{ Item } & \multicolumn{10}{|c|}{ Answer } & \multirow{3}{*}{$\mathrm{N}$} & \multirow{3}{*}{$\begin{array}{l}\text { Total } \\
\text { Score }\end{array}$} & \multirow{3}{*}{ Mean } \\
\hline & \multicolumn{2}{|c|}{5} & \multicolumn{2}{|c|}{4} & \multicolumn{2}{|c|}{3} & \multicolumn{2}{|c|}{2} & \multicolumn{2}{|c|}{1} & & & \\
\hline & $\mathrm{F}$ & $\%$ & $\mathrm{~F}$ & $\%$ & $\mathrm{~F}$ & $\%$ & $\mathrm{~F}$ & $\%$ & $\mathrm{~F}$ & $\%$ & & & \\
\hline Q33 & 11 & 22 & 38 & 76 & 1 & 2 & 0 & 0 & 0 & 0 & 50 & 210 & 4.20 \\
\hline Q34 & 0 & 0 & 0 & 0 & 13 & 26 & 30 & 60 & 7 & 14 & 50 & 106 & 2.12 \\
\hline Q35 & 8 & 16 & 36 & 72 & 6 & 12 & 0 & 0 & 0 & 0 & 50 & 202 & 4.04 \\
\hline Q36 & 9 & 18 & 37 & 74 & 4 & 8 & 0 & 0 & 0 & 0 & 50 & 205 & 4.10 \\
\hline Q37 & 1 & 2 & 31 & 62 & 18 & 36 & 0 & 0 & 0 & 0 & 50 & 183 & 3.67 \\
\hline Q38 & 11 & 22 & 33 & 66 & 6 & 12 & 0 & 0 & 0 & 0 & 50 & 205 & 4.10 \\
\hline Q39 & 5 & 10 & 15 & 30 & 30 & 60 & 0 & 0 & 0 & 0 & 50 & 175 & 3.50 \\
\hline Q40 & 3 & 6 & 26 & 52 & 19 & 38 & 2 & 4 & 0 & 0 & 50 & 180 & 3.60 \\
\hline Q41 & 22 & 44 & 22 & 44 & 6 & 12 & 0 & 0 & 0 & 0 & 50 & 216 & 4.32 \\
\hline \multicolumn{11}{|c|}{ Total Variable Teacher Job Satisfaction } & & & 33.64 \\
\hline \multicolumn{13}{|c|}{ The average variable Teacher Job Satisfaction } & 3.74 \\
\hline
\end{tabular}

Sources: Primary data is processed in 2019

From Table 11 above it can be seen that on the 9 items 50 respondents answer on job satisfaction of teachers for the average item score the performance of teachers (X3) of 3.74, thus indicating that respondents tend to agree that the job satisfaction of teachers to contribute to the Quality of Education.

Description varibael Education Quality

Table 12 Education Quality variable Y

\begin{tabular}{|c|c|c|c|c|c|c|c|c|c|c|c|c|c|}
\hline \multirow{3}{*}{ Item } & \multicolumn{10}{|c|}{ Answer } & \multirow{3}{*}{$\mathrm{N}$} & \multirow{3}{*}{$\begin{array}{l}\text { total } \\
\text { Score }\end{array}$} & \multirow{3}{*}{ Mean } \\
\hline & \multicolumn{2}{|r|}{5} & \multicolumn{2}{|c|}{4} & \multicolumn{2}{|r|}{3} & \multicolumn{2}{|c|}{2} & \multicolumn{2}{|c|}{1} & & & \\
\hline & $\mathrm{F}$ & $\%$ & $\mathrm{~F}$ & $\%$ & $\mathrm{~F}$ & $\%$ & $\mathrm{~F}$ & $\%$ & $\mathrm{~F}$ & $\%$ & & & \\
\hline Q42 & 16 & 32 & 34 & 68 & 0 & 0 & 0 & 0 & 0 & 0 & 50 & 216 & 4.32 \\
\hline Q43 & 12 & 24 & 35 & 70 & 3 & 6 & 0 & 0 & 0 & 0 & 50 & 209 & 4.20 \\
\hline Q44 & 10 & 20 & 27 & 54 & 13 & 26 & 0 & 0 & 0 & 0 & 50 & 197 & 3.94 \\
\hline Q45 & 4 & 8 & 27 & 54 & 19 & 38 & 0 & 0 & 0 & 0 & 50 & 185 & 3.70 \\
\hline Q46 & 6 & 12 & 34 & 68 & 10 & 20 & 0 & 0 & 0 & 0 & 50 & 196 & 3.92 \\
\hline Q47 & 5 & 10 & 37 & 74 & 8 & 16 & 0 & 0 & 0 & 0 & 50 & 197 & 3.94 \\
\hline Q48 & 19 & 38 & 27 & 54 & 4 & 8 & 0 & 0 & 0 & 0 & 50 & 215 & 4.30 \\
\hline Q49 & 12 & 24 & 36 & 72 & 2 & 4 & 0 & 0 & 0 & 0 & 50 & 206 & 4.12 \\
\hline Q50 & 8 & 16 & 42 & 84 & 0 & 0 & 0 & 0 & 0 & 0 & 50 & 208 & 4.17 \\
\hline Q51 & 10 & 20 & 39 & 78 & 1 & 2 & 0 & 0 & 0 & 0 & 50 & 209 & 4.18 \\
\hline \multicolumn{11}{|c|}{ Total Variable Quality of Education } & & & 40.77 \\
\hline \multicolumn{13}{|c|}{ The average variable Quality of Education } & 4.08 \\
\hline
\end{tabular}

Sources: Primary data is processed in 2019

From the table above it can be seen that 12 of the 10 items of 50 respondents answer about the quality of education for the average item score the quality of education (Y) at 4.08 thereby indicating that respondents tend to agree that is able to contribute to the quality of education. 
Figure 2. Test Normality

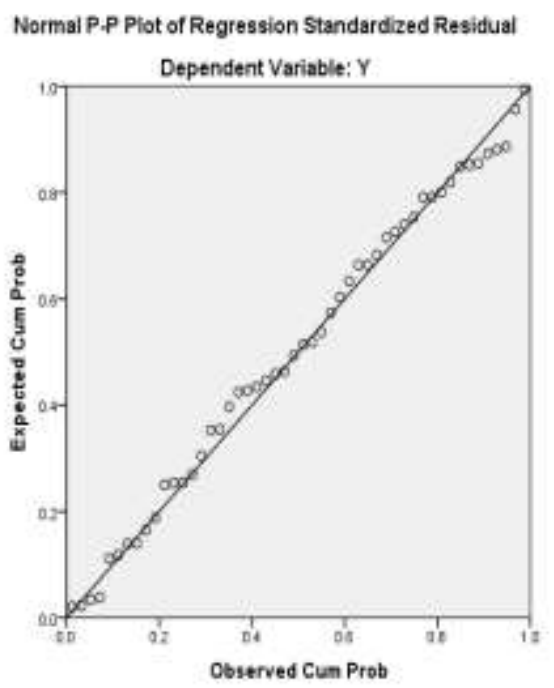

Sources: Primary data is processed in 2019

The image shows that the data spreaders around and approached the diagonal line indicates that the research data that includes the variable of school leadership, motivation and job satisfaction of teachers.

Figure 3. Test Heterokedastitas

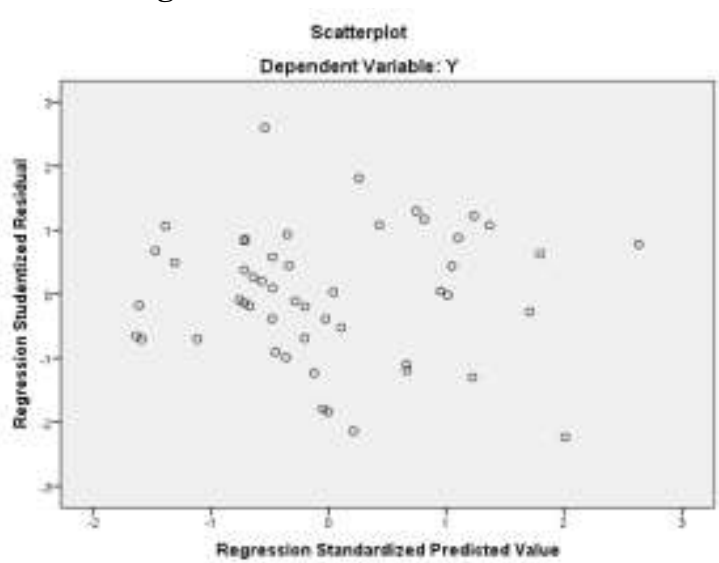

Source: Data Processed in 2019

Based on the pictures, it looks dots spread randomly, do not form a pattern of clear and well spread above or below the number 0 on the $\mathrm{Y}$ axis. This means do not occur heteroscedasticity in regression models.

Table 13. Test Multicolinearity

\begin{tabular}{|c|l|c|c|}
\hline \multirow{2}{*}{ No } & \multicolumn{2}{|}{ The independent variable } & \multicolumn{2}{|c|}{ Collierity Statistics } \\
\cline { 3 - 4 } & & Tolerence & VIF \\
\hline 1 & Leadership Principal (X1) & 0.793 & 1.262 \\
\hline 2 & Work Motivation (X2) & 0.623 & 1,605 \\
\hline 3 & Teacher Job Satisfaction (X3) & 0.732 & 1,366 \\
\hline
\end{tabular}

Sources: Primary data is processed in 2019.

Based on the results penghitunganVIF seen that variable Principal Leadership, Work Motivation and Job Satisfaction Teachers have $\operatorname{VIF}<5$, thus it can be concluded that there is no regression model multicollinearity problem. 
International Journal of Advances in Scientific Research and Engineering (ijasre), Vol 5 (11), November-2019

Table 14. Summary of Results of Multiple Regression Analysis

\begin{tabular}{|c|c|c|c|c|}
\hline Variebel & Regression Coefficients & $\mathrm{t}$ & Sig & Information \\
\hline Leadership Principals (x1) & 0.256 & 4.074 & 0.000 & Significant \\
\hline Motivation (x2) & 0.164 & 2.042 & 0.047 & Significant \\
\hline Teacher Job Satisfaction (x3) & 0.353 & 2.565 & 0.014 & Significant \\
\hline Constants & 0.513 & & & \\
\hline $\mathrm{R}$ & 0,729 & & & \\
\hline Adjusted R Square & 0,531 & & & \\
\hline F count & 17.343 & & & \\
\hline Sig. F & 0,000 & & & \\
\hline $\mathrm{N}$ & 50 & & & \\
\hline \multicolumn{5}{|c|}{ The dependent variable: Quality of Education } \\
\hline \multicolumn{5}{|l|}{ F table: 2,79} \\
\hline table: 2,00 & & & & \\
\hline
\end{tabular}

Table 15. Results of Test F

\begin{tabular}{|c|c|c|c|c|c|c|}
\hline \multicolumn{7}{|c|}{ ANOVA $^{\mathrm{b}}$} \\
\hline \multicolumn{2}{|c|}{ Model } & Sum of Squares & Df & mean Square & $\mathrm{F}$ & Sig. \\
\hline \multirow[t]{3}{*}{1} & Regression & 230728 & 3 & 76 909 & 17343 & $.000^{\mathrm{a}}$ \\
\hline & residual & 203992 & 46 & 4435 & & \\
\hline & Total & 434720 & 49 & & & \\
\hline
\end{tabular}

Sources: Primary data is processed in 2019

Based on Table 15 above, the value of $\mathrm{F}$ indicates a significant level of $0.00<\alpha 0.05$, so it can be concluded that the school leadership, motivation and job satisfaction of teachers simultaneously significant effect on educational quality. Thus the first hypothesis is accepted [9].

The second hypothesis testing. To test the first hypothesis which states that the alleged principal leadership, motivation and job satisfaction of teacherspartially significant effect on the quality of education, it will be determined by $t$ test. The t-test is used to determine the regression coefficient (beta) (The Goddess, 2015) each independent variable. To determine where the dominant influence variables can be seen in the following table:

Table 16. Results of $t$ Test

\begin{tabular}{|c|c|c|c|c|c|c|}
\hline & \multirow[t]{2}{*}{ Variables } & \multicolumn{2}{|c|}{$\begin{array}{c}\text { Coefficients } \\
\text { Unstandardized }\end{array}$} & \multirow{2}{*}{$\begin{array}{c}\begin{array}{c}\text { Standardized } \\
\text { Coefficients }\end{array} \\
\text { beta }\end{array}$} & \multirow[t]{2}{*}{$\mathrm{t}$} & \multirow[t]{2}{*}{ Sig. } \\
\hline & & B & Std. Error & & & \\
\hline \multirow[t]{4}{*}{1} & (Constant) & 0.513 & 5,790 & & 0.089 & 0.930 \\
\hline & Leadership Principal & 0.256 & 0.063 & 0.462 & 4.074 & 0.000 \\
\hline & Work motivation & 0.164 & 0.080 & 0.261 & 2.042 & 0.047 \\
\hline & Teacher Job Satisfaction & 0.353 & 0.138 & 0.303 & 2.565 & 0.014 \\
\hline
\end{tabular}

Sources: Primary data is processed in 2019.

Based on the above Table 16 shows that the value of the variable $t$ significance of school leadership by $0.000 \leq \alpha=0.05$, this shows the principal's leadership is partially significant effect on educational quality. Work motivation variable indicates the significant value of $0.047 \leq \alpha t=0.05$, it indicates the working motivation partially significant effect on the quality of education. Variable krja teacher satisfaction showed significant value thitung $0.014 \leq \alpha=0.05$, this indicates a partial job satisfaction of teachers significantly influence the quality of education. Thus the second hypothesis is accepted [10].

The third hypothesis testing. To test the hypothesis tothree states in the suspect variable Teacher Job Satisfaction dominant influence on the quality of education, then the details can be measured throught test. The t-test is used to determine the regression coefficient (beta) of each variable bebasdan independent variables which are dominant as in table 16 [11]. 


\section{CONCLUSION}

Results Descriptive statistics show thatschool leadershipable to contribute to the quality of education to engage with teachers in giving new ideas in learning, The main thing is to support school leadership engage with educators, fostering a harmonious relationship and reward outstanding teachers to build on the progress of educational institutions [12]. Rewarding teachers can affect job satisfaction of teachers. Job satisfaction teachers formed in order to maximize its obligations as a teacher, to improve the quality of education in SMPK Kolose St. Yusuf 2 Malang.

School leadership, motivation and job satisfaction of teachers simultaneously affect the quality of education in SMPK Kolose St. Yusuf 2 Malang, which means that the better school leadership, which supported the work motivation, job satisfaction and supported the teachers can improve the quality of education in SMPK Kolose St. Yusuf 2 Malang. School leadership, motivation and job satisfaction of teachers partially influence the quality of education in SMPK Kolose St. Yusuf 2 Malang. This suggests that the motivation and job satisfaction of teachers can be enhanced through an adequate level of teacher education, supporting infrastructure and facilities are complete and harmonious working environment.

Influential teacher job satisfaction dominant the quality of education in SMPK Kolose St. Yusuf 2 Malang. This suggests that the main effect of which can increase the job satisfaction of teachers in SMPK Kolose St. Yusuf 2 Malang ie teachers are awarded when performance is good [13]. Good performance in terms of skilled teachers and understanding in identifying the needs of the learning program plan. Needs learning program is meant is skill in identifying what things are needed in the course of classroom management, use of media and learning resources, and the use of methods and learning strategies. By giving the award to the teacher teaching skills will remain good even be better in order to achieve a good quality of education in SMPK Kolose St. Yusuf 2 Malang.

\section{REFERENCES}

1. Khaerunnisa, I., Sari, E., Ulfah, M., Jakaria, \& Sumantri, C. (2013). Jurnal 4. Media Peternakan, Vol. 36, pp. 85-90. https://doi.org/10.5398/medpet.2013.36.2.85

2. Suharsono, Riyanto ; Rahmasari, Gusti Putu Ayu, 2016. (2016). Jurnal 1. Pengaruh Pengungkapan Corporate Social Responsibility (CSR) Terhadap Cost of Capital (COC) Dengan Kepemilikan Institusional Sebagai, Vol. 109, pp. 109119.

3. Christina M. Fuad Sugiarto dan Edy Sukarno, E. (2012). Jurnal 6. Anggaran Perusahaan.

4. Hansen, D. R. dan M. M. M. (2015). Jurnal 7. Akuntansi Manajemen, Vol. 2, p. 358.

5. Muhammad Munandar. (2013). Jurnal 9. Perencanaan Kerja, Pengkoordinasian Kerja Dan Pengawasan Kerja, pp. 49-54.

6. Muhammad Nafarin. (2013). Jurnal 10. Penganggaran Perusahaan, pp. 9-167.

7. Horngren, Charles T. George Foster, and S. M. D. (2013). Jurnal 8. Cost Accounting: A Managerial Emphasis, p. 17.

8. Prasetyo Widyo Iswara. (2016). Jurnal 11. Anggaran Perusahaan, p. 5.

9. Stoner, J. A. F. and R. E. F. (2015). Jurnal 12. Management, p. 105.

10. Murwati, H., Studi, P., Ekonomi, P., Pendidikan, B., \& Niaga, T. (2013). Pengaruh Sertifikasi Profesi Guru Terhadap Motivasi Kerja Dan Kinerja Guru Di Smk Negeri Se-Surakarta. Jurnal Pendidikan Bisnis Dan Ekonomi (BISE), 1(1), 1221. Retrieved from http://www.geocities.ws/guruvalah/mutu_gur

11. Ardiana, T. E. (2017). Pengaruh Motivasi Kerja Guru Terhadap Kinerja Guru Akuntansi Smk Di Kota Madiun. Jurnal Akuntansi Dan Pajak, 17(02), 14-23. https://doi.org/10.29040/jap.v17i02.11

12. Santika, P., \& Sudibya, G. (2017). Pengaruh Kelelahan Emosional Terhadap Kepuasan Kerja Dan Komitmen Organisasional. E-Jurnal Manajemen Universitas Udayana, 6(2), 145-154.

13. Rahayu, S. (2017). Komunikasi Interpersonal Kepemimpinan Kepala Sekolah dan Budaya Kerja Organisasi terhadap Motivasi Kerja Dan Dampaknya pada Kepuasan Kerja Guru Sekolah Menengah Pertama. Manajemen Pendidikan, 12(1), 73. https://doi.org/10.23917/jmp.v12i1.2977 